\title{
The usefulness of fermented katuk (Sauropus androgynus) plus bay leaves to modify fat accumulation, cholesterol and chemical composition of broiler meat
}

\author{
U. Santoso*, Y. Fenita and Kususiyah \\ Animal Husbandry Department, Agriculture Faculty, University of Bengkulu, \\ Jln. W.R. Soepratman, Kota Bengkulu - Indonesia \\ *Corresponding E-mail: santoso@unib.ac.id
}

Received December 21, 2018; Accepted January 22, 2019

\begin{abstract}
ABSTRAK
Dampak positif penambahan herbal fermentasi (daun katuk plus daun salam) terhadap akumulasi lemak, komposisi proksimat, dan profil asam amino dan asam lemak dalam daging telah diteliti. Pada umur 14 hari, 280 ayam pedaging betina dibagi menjadi tujuh perlakuan, yaitu: T0) kontrol, ayam pedaging diberi pakan tanpa herbal; T1) ayam pedaging diberi pakan dengan herbal formula 1 sebesar 2,5\%; T2) ayam pedaging diberi pakan dengan herbal formula 2 sebesar 2,5\%; T3) ayam pedaging diberi pakan dengan herbal formula 3 pada $2,5 \%$; T4) ayam pedaging diberi pakan dengan herbal formula 1 sebesar 5\%; T5) ayam pedaging diberi pakan dengan herbal formula 2 sebesar 5\%; T6) ayam pedaging diberi pakan dengan herbal formula 3 sebesar 5\%. Hasil penelitian menunjukkan bahwa pemberian herbal menurunkan penimbunan lemak perut, lemak rempela dan lemak total, kadar lemak dan kolesterol daging. Selain itu, pemberian herbal mengubah kadar kalsium, besi, air, serin, treonin, arginin, valin, lisin, metionin, asam miristat, asam pentadekanoat, asam palmitat, asam oleat, asam linolenat, asam cis-11,14-eikosedienoik, asam cis-5,8,11,14,17-eikosapentaenoik dan asam lemak tak jenuh n-3 dalam daging. Dapat disimpulkan bahwa pemberian herbal formula 2 sebanyak 5\% menghasilkan daging ayam dengan kadar lemak dan kolesterol yang rendah, tetapi kadar protein, mineral dan asam lemak tak jenuh n-3 yang lebih tinggi.

Kata kunci: daun katuk, daun salam, penimbunan lemak, kolesterol, komposisi gizi daging, ayam pedaging
\end{abstract}

\begin{abstract}
The usefulness of the addition of fermented herbs (katuk/Sauropus androgynus plus bay leaves) on fat accumulation, and chemical, amino acids and fatty acids composition of broiler meats was investigated. At 15 days of age, 280 female broilers were divided into seven treatments, as follows: T0) the control; T1) broilers were given a ration with $2.5 \%$ fermented katuk plus bay leaf mixture formula 1 ; T2) broilers were given a ration with $2.5 \%$ fermented katuk plus bay leaf mixture formula 2; T3) broilers were given a ration with $2.5 \%$ fermented katuk plus bay leaf mixture formula 3 ; T4) broilers were given a rations with $5 \%$ fermented katuk plus bay leaf mixture formula $1 ; \mathrm{T} 5)$ broilers were given a ration with $5 \%$ fermented katuk plus bay leaf mixture formula 2; T6) broilers were given a ration with $5 \%$ fermented katuk plus bay leaf mixture formula 3. The results of this study showed that the administration of fermented herbs to the ration significantly reduced abdominal fat, gizzard fat, total fat deposition, meat fat, and cholesterol contents. Their inclusions changed calcium, iron, moisture, serine, threonine, arginine, valine, lysine, methionine, myristic acid, pentadecanoic acid, palmitic acid, oleic
\end{abstract}


acid, linolenic acid, cis-11,14-eicosadienoic acid, cis-5,8,11,14,17-eicosapentaenoic acid, and n-3 unsaturated fatty acids of female broiler meats. It can be concluded that administration of fermented herbs formula 2 at $5 \%$ levels produced chicken meat with lower fat and cholesterol levels, but higher protein, minerals and n-3 unsaturated fatty acids levels.

Keywords: Sauropus androgynus leaf, bay leaf, fat accumulation, cholesterol, proximate composition, female broilers

\section{INTRODUCTION}

Medicinal plants and their products have widely been investigated to substitute antibiotic and to modify poultry quality, such as tuchung leaf (Santoso et al., 2000), katuk (Sauropus androgynus) leaf powder (Santoso and Sartini, 2001), katuk leaf extract (Santoso et al., 2010c), bay leaf (Santoso et al., 2017, 2018) and other medicinal plants. Katuk leaf contains several active compounds that are capable to modify broiler meats, such as $\beta$-carotene (Santoso et al., 2015b), linolenic acid, palmitic, acid, benzoic acid and chlorophyll (Samad et al., 2014), vitamin C (Khoo et al., 2015), $\alpha$-tocopherol (Platel and Srinivasan, 2017), mineral (Santoso et al., 2015; Santoso et al., 2017), polyphenols (Qiong et al., 2014), flavonoids (Zarrouki et al., 2010), saponins (Warditiani et al., 2016), alkaloids (Santoso et al., 2010b) and tannin (Selvi and Bhaskar, 2012). In the other hand, bay leaf contains flavonoids and glycosides (Ayoub et al., 2013; Abu-Dahab et al., 2014), volatile compounds, potassium, phosphorus and vitamin A activity (Pharthasarathy et al., 2008), flavonoids, triterpenoids, phenols, saponins and tannins (Santoso et al., 2017). Rahim et al. (2018) reported that bay leaf contained squalene, phytol, $\alpha$-pinene, $\alpha$-tocopherol, $\beta$-sitosterol, pyrogallol, and unknown compounds.

Santoso et al. (2017) compared six medicinal plants to modify meat composition and quality and found that Sauropus androgynus or bay leaves inclusion were more effective than other four medicinal plants (papaya leaf, basil leaf, noni fruit and Moringa leaf). Sauropus androgynus leaf was more effective to lower fat content and to increase protein and iron contents, but less effective to reduce cholesterol content as compared with bay leaf. Adriani et al. (2012) reported that feeding $3 \%$ bay leaf reduced meat cholesterol contents of quails, whereas Narahari et al. (2005) found that $0.5 \%$ bay leaf inclusion reduced egg cholesterol.

The development of feed supplements from medicinal plant ingredients requires several medicinal plants to produce effective formulas.
Kiyohara et al. (2004) state that formulas with many medicinal plants are expected to show a positive combination effect of many of these medicinal plants. Thus, the inclusion of katuk and bay leaf mixture may result in better meat quality than a single plant. However, katuk leaves and bay leaves contain high crude fiber and some antinutrient compounds and minerals that are not ready for use. For this reason, katuk leaves and bay leaves need to be improved in quality. One of a method to improve the quality of feedstuffs is fermentation.

Fermentation reduces anti-nutrition and crude fiber, improves nutrient values and feed utilization in poultry, ileal nutrients and amino acid digestibilities and mineral availability (Ahmed et al., 2014; Ari et al., 2012; Olaniyi and Mehhizadeh, 2013; Olagunyu and Ifesan, 2013; Sukaryana et al., 2011), and modifies lipid profiles (Santoso et al., 2010a).

Santoso et al. (2015a) found that fermented katuk leaf reduced fat deposition in the liver and adipose tissue. Santoso et al. (2015b) reported that $5 \%$ cassava yeast fermented katuk leaf inclusion reduced fat and cholesterol contents, increased vitamin A, $\beta$ carotene, protein and iron contents, and changes amino acid and fatty acid profiles in broiler meats. Lee at al. (2017) reported that the inclusion of fermented agricultural by-products reduced crude fat, but increased the protein content of broiler meat.

This research was done to analyze the use of fermented herbs (katuk-bay leaf mixture) on fat accumulation, cholesterol, proxymate composition, amino acid and fatty acid profiles in female broilers.

\section{MATERIALS AND METHODS}

\section{Fermentation of Katuk and Bay Leaves}

The leaves obtained from the field or from traditional markets were air-dried for 5 days, and then dried under the sun for 1 hour for a dryness rate of about $10-12 \%$, milled and stored in a plastic bag. The leaves powder was added water with 1:1 ratio, and then was cooked for 30 
minutes. The cooled leaves were then added with $0.5 \%$ cassava yeast and fermented for 24 hours at anaerobic condition. The fermented leaves were then dried under the sun, milled and stored in sealed plastic bag.

\section{Animals and Diets}

Seven hundred one day old chicks were given sugar contained drinking water to reduce stress due to travel. Brooder temperature was set according to standard maintenance procedure. At the age of 4 and 21 days, broiler chickens were vaccinated ND. At the age of 1-14 days, broiler chickens were fed commercial diets. At 14 days of age, 280 female broiler chickens were weighed and selected.

At 15 days of age, 280 female broilers were divided into seven treatments, as follows: T0) the control; T1) broilers were given a ration with $2.5 \%$ fermented katuk plus bay leaf mixture formula 1; T2) broilers were given a ration with $2.5 \%$ fermented katuk plus bay leaf mixture formula 2; T3) broilers were given a ration with $2.5 \%$ fermented katuk plus bay leaf mixture formula 3 ; T4) broilers were given a rations with $5 \%$ fermented katuk plus bay leaf mixture formula 1; T5) broilers were given a ration with $5 \%$ fermented katuk plus bay leaf mixture formula 2; T6) broilers were given a ration with $5 \%$ fermented katuk plus bay leaf mixture formula 3 .

The experimental diets (crude protein of T0, T1, T2, T3, T4, T5, and T6 was $19.86 \%, 19.82 \%$, $19.79 \%, 19.75 \%, 20.09 \%, 20.02$, and 19,95\%, respectively, whereas metabolizable Energy of T0, T1, T2, T3, T4, T5, and T6 was 3088.07, 3097.63. 3096.93, 3096.22, 3070.26, 3068.85, and 3067.44 $\mathrm{kcal} / \mathrm{kg}$ ) were published elsewhere (Santoso et al., 2018). All treatments were designed consisting of 7 treatments where each treatment consisted of 4 replications. Each replication contained 10 female broilers. Broiler maintenance standard was referred to in this study. Ration and drinking water were provided sufficiently throughout the day. Broiler chickens were maintained until 34 days of age.

\section{Sampling}

At 34 days of age, six selected female broilers for each treatment were slaughtered. The accumulation of fat in the abdomen, gizzard, leg meats, heart, and neck were taken and weighed. To measure fatty liver scores, the colors of the broiler livers were compared with the standard colors from 1 to 5 (from dark brown (value 1) to yellowish white (value 5). The higher the value, the higher the fat content. The broiler thigh meats were taken, milled and frozen before analysis.

\section{Laboratory Analysis}

Fat content was analyzed by Soxhlet extraction; moisture content was analyzed by drying the samples at $105^{\circ} \mathrm{C}$; and protein content was analyzed using micro kjeldahl (Yerina (2015). Cholesterol levels were measured according to Liebermen-Burchrad with several modification as follows. 0.1 gram of sample was added $10 \mathrm{~mL}$ of alcohol:hexane (3:1), heated and after cold centrifuged at $3.000 \mathrm{rpm}$ for 10 minutes. The supernatant was separated, evaporated until a paste was formed. The paste was dissolved in chloroform and homogenized, and then added 2 $\mathrm{mL}$ of a mixture of sulfuric acid and acetic anhydrous (1:30)). After that it was placed in the dark room for 25 minutes until a green color was formed, read with a spectrophotometer with a wavelength of $420 \mathrm{~nm}$ (Marfuah, 2016).

Amino acid composition was measured by the method described by Ginting et al. (2017). Sixty milligrams of broiler thigh meat in erlenmeyer were added $4 \mathrm{ml}$ of $6 \mathrm{~N} \mathrm{HCl}$ and refluxed for 24 hours at $110^{\circ} \mathrm{C}$. The results of hydrolysis were neutralized with $\mathrm{NaOH} 6 \mathrm{~N}$ and filtered with $0.2 \mu \mathrm{m}$ wattman paper. $50 \mu \mathrm{l}$ was taken and $300 \mu \mathrm{L}$ OPA (O-phthalaldehyde) solution and 1-2 drops of 2-mercaptoetanol was added, and stirred for 5 minutes. Furthermore, a sample of $20 \mu \mathrm{L}$ was inserted into the HPLC injector alternately and ready for analysis.

Twenty gram broiler thigh meat was dried at $90^{\circ} \mathrm{C}$ for 24 hours. The sample was extracted in soxhlet for 16 hours. The extraction was concentrated at $55^{\circ} \mathrm{C}$ for 2 hours. A total of 0.0298 $\mathrm{g}$ of sample was added to $1 \mathrm{~mL}$ of $\mathrm{NaOH} 0.5 \mathrm{~N}$ within methanol and heated over a water bath at $80^{\circ} \mathrm{C}$ for 20 minutes. After cooling, $2 \mathrm{~mL} \mathrm{BF} 3$ was added and heated at $80^{\circ} \mathrm{C}$ for 20 minutes, then cooled and added $2 \mathrm{~mL}$ of saturated $\mathrm{NaCl}$ and 1 $\mathrm{mL}$ of hexane. The hexane layer was separated by a drop pipette and put in a tube containing 0.1 gram of Na2SO4 anhydrous, and left for 15 minutes. Sample solutions were separated and ready to be injected. The fatty acid composition was then measured by gas chromatography (Breuer et al., 2013).

Data obtained during the study were analyzed using one-way ANOVA. DMRT test was used if the measured variables had a significant 
effect at the 5\% level (SPSS version 21).

\section{RESULTS AND DISCUSSION}

\section{Fat Accumulation}

The Effect of fermented katuk and bay leaves on fat deposition in female broiler chickens is presented in Table 1. It was shown that the fat accumulation in the abdomen and gizzard was significantly affected $(\mathrm{P}<0.01)$, but the fat accumulation in sartorial, neck and heart was not affected. ( $\mathrm{P}>0.05)$. The fatty liver score did also not changed. It was shown that $\mathrm{T} 4$ and $\mathrm{T} 5$ had lower abdominal fat than T1, T2, T3, and T6 but statistically similar to $\mathrm{T} 0$. T4 had lower gizzard fat than the other treatment groups. T4 had lower total fat deposition than $\mathrm{T} 0, \mathrm{~T} 1, \mathrm{~T} 2, \mathrm{~T} 3$, and $\mathrm{T} 6$ but statistically similar to $\mathrm{T} 5$. The results showed that broilers fed a diet with fermented herbs 1 at the $5 \%$ level (T4) had the lowest total fat deposition.

The results showed that broilers fed a diet with fermented herbs 1 at the 5\% level (T4) had the lowest total fat deposition. Lower fat deposition in T4 may be caused by active components presented in katuk and bay leaves such as flavonoids (Kamboh and Zhu, 2013), tannins (Selvi and Bhaskar, 2012), saponins (Afrose et al., 2010) and phenols (Qiong et al., 2014). Lower fat accumulation could be caused by several mechanisms such as lower pancreatic lipase activity (Mahmoud et al.,2013), and/or adipocyte size and number (Joo et al., 2010). Katuk and bay leaves are rich in flavonoids such as quercetin and kaempferol (Santoso et al., 2017). Flavonoids such as quercetin (Srobel et al., 2005) reduce adipocyte differentiation resulting in lower adipogenesis and thus resulting in lower adipocyte size and number. Phenolic compounds also reduce visceral adiposity by lowering adipocyte cell number and adipocyte cell size (de Melo et al., 2017).

\section{Proxymate Composition of Meats}

The Effect of fermented katuk and bay leaves on meat composition of female broiler chickens is presented in Table 2. This research showed that the addition of fermented herbs significantly affected fat, cholesterol, calcium, iron $(\mathrm{P}<0.05)$. phosphorus and moisture contents $(\mathrm{P}<0.01)$ but it did not significantly change protein and ash contents. Higher fat content was found in $\mathrm{T} 0$ as compared with $\mathrm{T} 2, \mathrm{~T} 3, \mathrm{~T} 4, \mathrm{~T} 5$, and T6. T0 was found to consist of higher moisture content than $\mathrm{T} 1, \mathrm{~T} 2, \mathrm{~T} 3, \mathrm{~T} 4$, and $\mathrm{T} 5 . \mathrm{T} 0$ was found to have higher cholesterol content than T4, $\mathrm{T} 5$, and T6. T0 significantly had lower calcium content than $\mathrm{T} 2$ and $\mathrm{T} 4$. T0 significantly had lower phosphorus content than T2, T3, T4, T5, and T6. T0 significantly had lower iron content than $\mathrm{T} 2$.

The herb mixture was formulated by fermented katuk and bay leaves at the certain combination. Santoso et al. (2018) found that the addition of katuk leaf or bay leaf at 5\% level reduced meat fat content by $26.7 \%$ or $10.0 \%$, respectively. It was shown that the fermented katuk and bay leaves reduced meat fat content ranging from $22.5 \%$ to $45.2 \%$. Broilers that provided a ration with $5 \%$ fermented herbs formula 2 had the lowest meat fat content. It appears that the combination of fermented herbs and feeding level influence meat fat content. A fermented product has been known to reduce the meat fat content in broiler chickens (Santoso et al., 2010a). A reduction in the meat fat content by fermented product was partly caused by a reduction of fatty acid synthesis (Nie et al., 2015). Flavonoids (Zarrouki et al., 2010), tannins (Selvi and Bhaskar, 2012) and phenols (Qiong et al., 2014) have been reported to have anti lipid properties. Li and Tian (2004) also reported that flavonoids inhibited fatty acid synthase activity.

Low cholesterol in broilers provided a ration with $5 \%$ fermented herbs (T4, T5, T6) might be caused by saponins, flavonoids, alkaloids, and other compounds. Broilers fed $0.9 \%$ saponins decreased lipid digestibility and marked increases in cholesterol excretion (Jenkins and Atwal, 1994), whereas flavonoids decreased cholesterol and triglyceride contents of adipose and liver (Nan et al., 2014). Amani et al. (2014) found that an increase in flavonoid intake reduced the concentration of total plasma cholesterol.

This research showed that the addition of fermented herbs tended to increase protein content. Santoso et al. (2015) found that the addition of $2.5 \%$ or $5 \%$ fermented katuk leaf increased meat protein content. Santoso et al. (2018) also found that the addition of 5\% katuk leaf powder increased meat protein content, whereas the inclusion of bay leaf tended to lower protein content. It has been established that fermentation improves protein values, protein digestibility and protein utilization, and ileal amino acid digestibilities in poultry (Ahmed et al., 2014; Cabuk et al., 2018; Sukaryana et al., 2011), and therefore increase protein retention in 


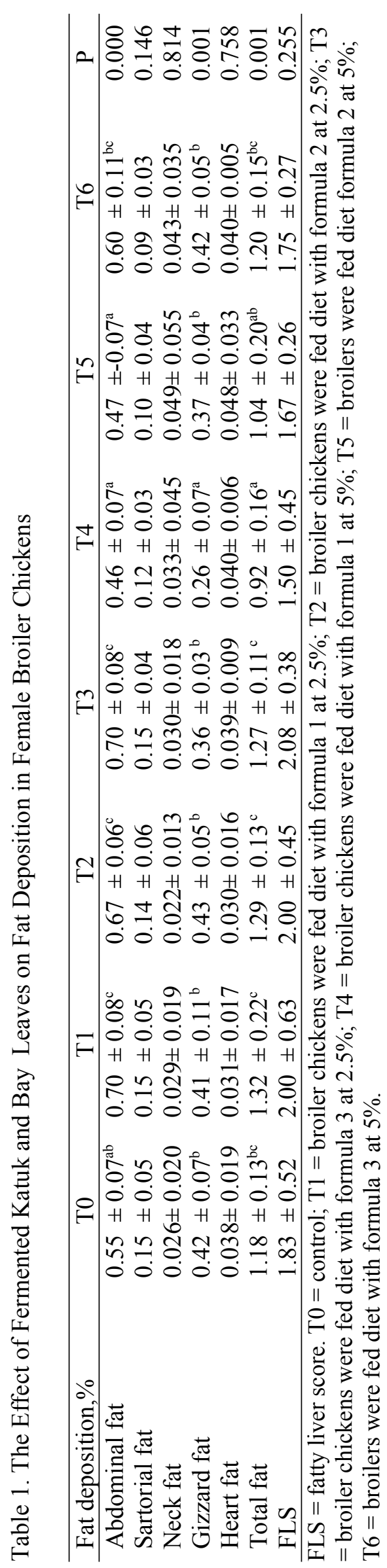

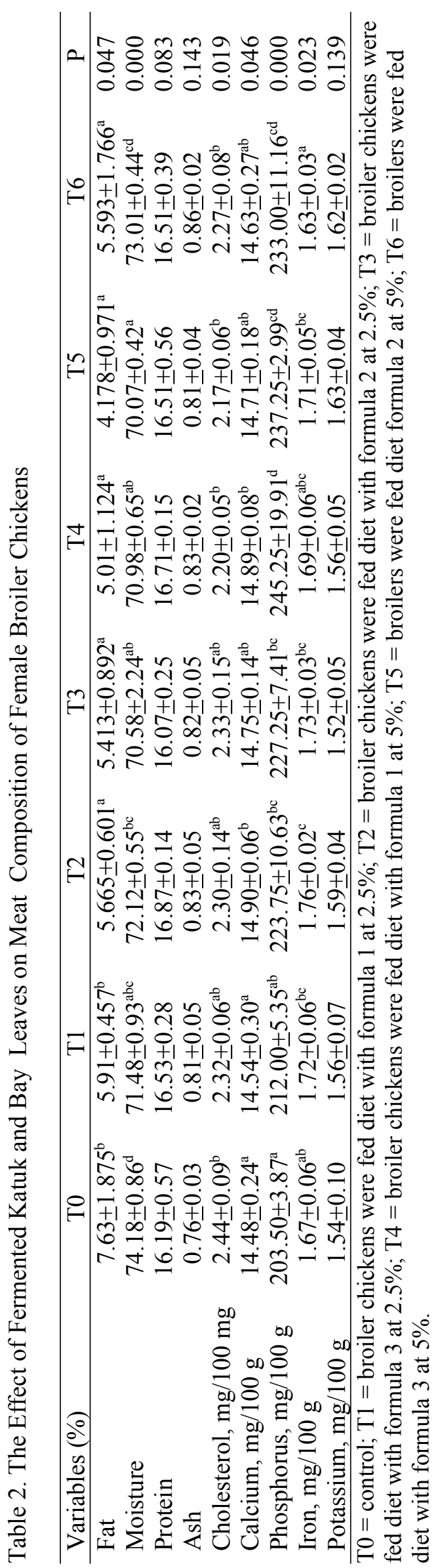




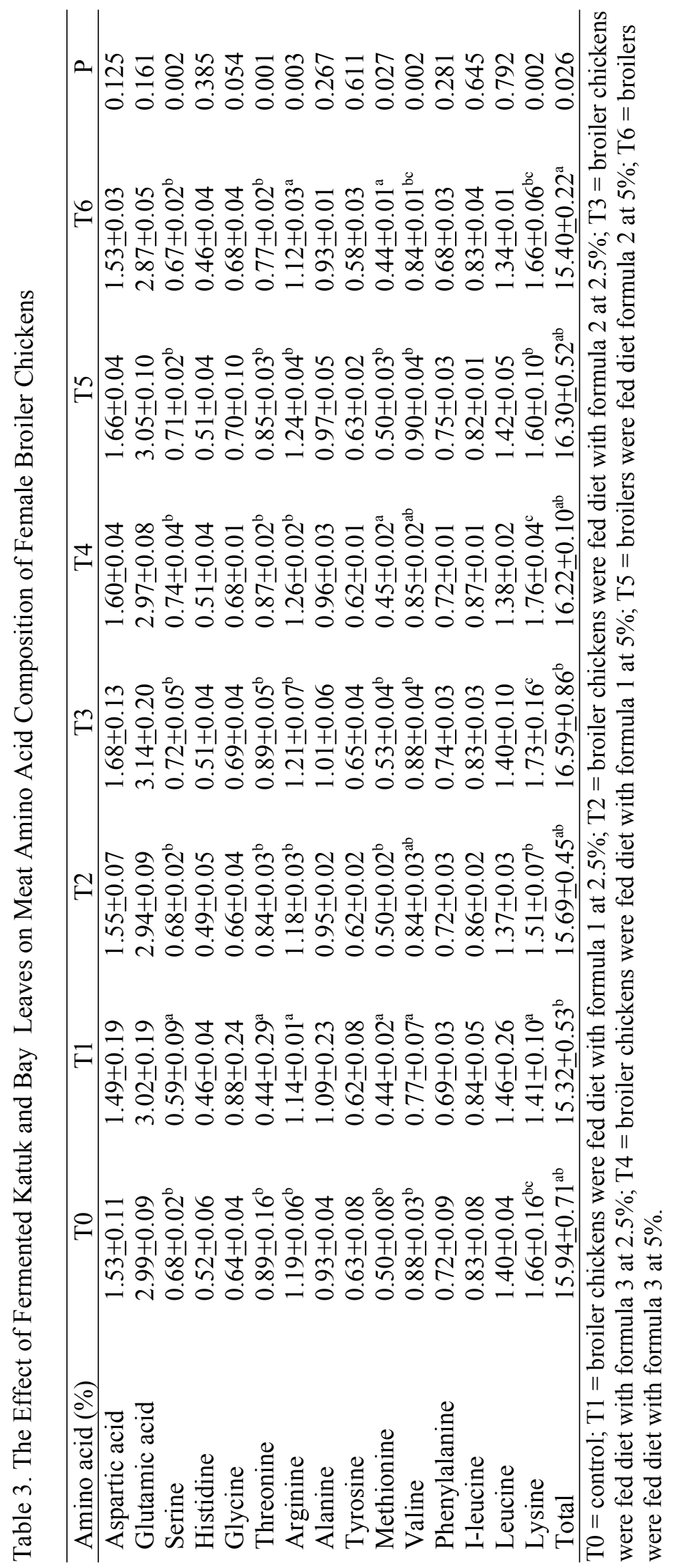




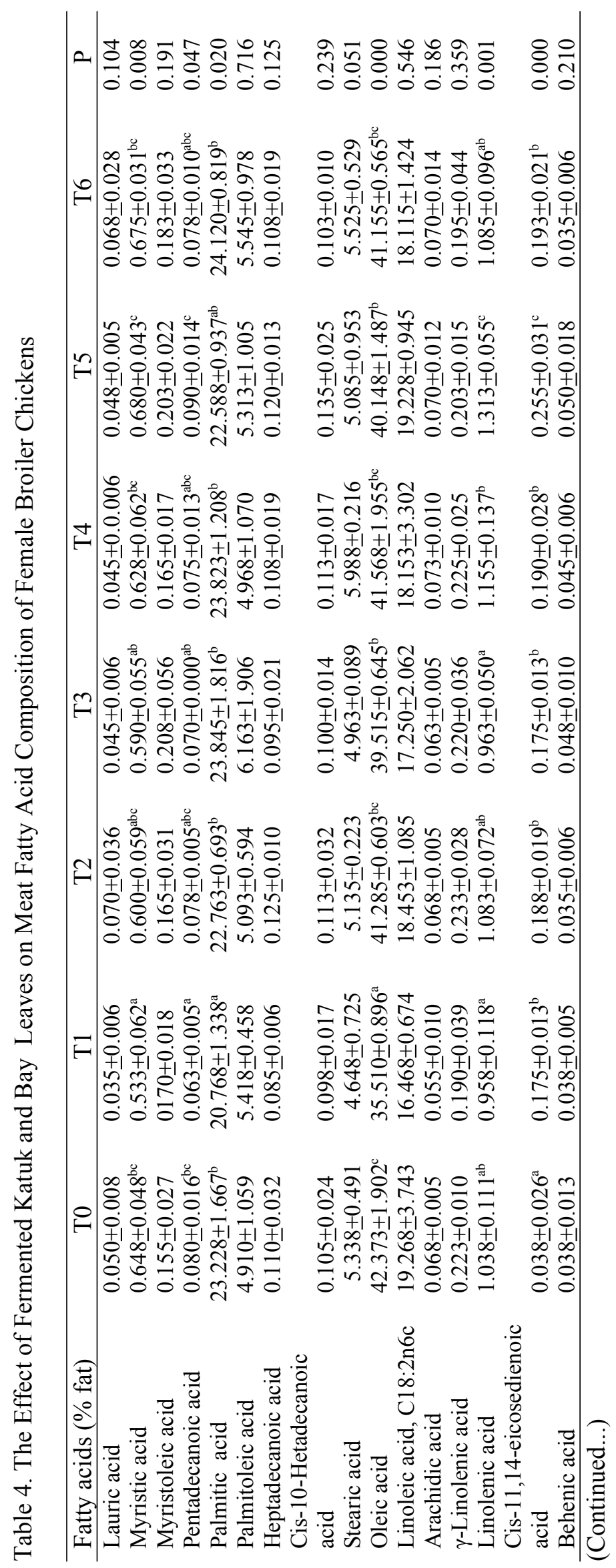


the body.

An increase in phosphorus content of broiler meat in $\mathrm{T} 2, \mathrm{~T} 3, \mathrm{~T} 4, \mathrm{~T} 5$, and $\mathrm{T} 6$, and improve calcium content in $\mathrm{T} 2$ and $\mathrm{T} 4$ might have a beneficial effect on human health. Calcium functions as muscle contraction and relaxation, transmission of nerve impulses, blood clots, regulating hormone secretion, co-factors in several enzymes, formation and maintenance of bone and teeth, smooth functioning of muscles, brain and nervous system (Shita and Sulistiyani, 2010), oocyte activation and fluid balance within cells (Praniva et al., 2013). Phosphate functions as skeletal mineralization (Takeda et al., 2004), intracellular signaling, membrane lipid component and the DNA backbone formation (Renkema et al., 2008). Furthermore, Plasma calcium and phosphate concentrations regulated the functions of various vital physiologic performances (Renkema et al., 2008). The tendency of higher meat iron content in broilers provided a ration with fermented herbs may be beneficial for a human. Iron has an important role in the transport of oxygen and electron, the synthesis of DNA, erythrocyte and hemoglobin, the conversion of blood sugar to energy, and the production of an enzyme (Gupta, 2014). Fermentation improves mineral bioavailability of mineral such as calcium, phosphorus and iron of feedstuffs (Gupta et al., 2015). Fermentation by yeast such as Saccharomyces cereviciae increases mineral bioavailability because of hydrolysis of phytate, folate biofortification and detoxification of mycotoxins (Hasan et al., 2014). Phytate forms strong chelate with calcium, magnesium, zinc, copper, iron and potassium. Thus, reducing phytate would result in better availability of phosphorus, calcium, magnesium, zinc, copper and potassium for broilers.

\section{Amino Acid Profile}

Table 3 shows the effect of fermented katuk and bay leaves on meat amino acid composition of female broiler chickens. The results of this research showed that fermented herb addition did not change aspartic acid, glutamic acid, histidine, glycine, alanine, tyrosine, phenylalanine, Ileucine, and leucine but significantly affected serine, threonine, arginine, valine, lysine $(\mathrm{P}<0.01)$, methionine and total amino acid $(\mathrm{P}<0.05)$. Serine, threonine and lysine contents of T1 were lower than the other treatment groups. Arginine levels of $\mathrm{T} 1$ and $\mathrm{T} 6$ were found to be lower than T0, T2, T3, T4, and T5. Methionine levels of $\mathrm{T} 1, \mathrm{~T} 4$, and $\mathrm{T} 6$ were lower than $\mathrm{T} 0, \mathrm{~T} 2$, $\mathrm{T} 3$, and T5. The highest valine level was found in T5.

The lower arginine, methionine, valine, serine, threonine and lysine in $\mathrm{T} 1$ are still not understood. It appears that feeding broilers with a diet containing fermented herbs formula 1 either at a level $2.5 \%$ or $5 \%$ did not benefit. Santoso et al. (2018) found that the addition of katuk or bay leaf powder increased or no change in methionine content.

\section{Fatty Acid Profile}

The effect of fermented katuk and bay leaves on meat fatty acid composition of female broiler chickens is presented in Table 4. These results showed that the addition of fermented herbs significantly influenced myristic acid, oleic acid, linolenic acid, cis-11,14-eicosadienoic acid, cis-5,8,11,14,17-eicosapentaenoic acid, saturated fatty acid, unsaturated fatty acid, n-3 unsaturated fatty acid $(\mathrm{P}<0.01)$, n-6 unsaturated fatty acid $(\mathrm{P}<0.01)$, total fatty acids $(\mathrm{P}<0.01)$, pentadecanoic acid and palmitic acid $(\mathrm{P}<0.05)$. Myristic acid of $\mathrm{T} 1$ was lower than $\mathrm{T} 0, \mathrm{~T} 4, \mathrm{~T} 5$, whereas pentadecanoic acid of $\mathrm{T} 1$ was lower than $\mathrm{T} 0$ and T5. Palmitic acid level of T1 was found to be lower than T0, T2, T3, T4, and T6. Oleic acid level of $\mathrm{T} 1$ was found to be lower than $\mathrm{T} 0, \mathrm{~T} 2$, $\mathrm{T} 3$, T4, T5, and T6, whereas that of $\mathrm{T} 5$ was found to be lower than T0. Linolenic acid levels of T1 and $\mathrm{T} 3$ was found to be lower than T4 and T5. Cis-11,14-eicosadienoic acid level of P0 was found to be the lowest, whereas that of P5 was the highest. Cis-5,8,11,14,17-eicosapentaenoic acid level of T4 was found to be lower than T0, T1, T2, T3, and T5. Saturated fatty acid, unsaturated fatty acid, n-9 unsaturated fatty acid, and total fatty acid levels of T1 was the lowest.

Lower total fatty acid levels in $\mathrm{T} 1$ as compared with $\mathrm{T} 0$ is still not understood. Li and Tian (2004) reported that flavonoids inhibited fatty acid synthetase activity, a rate limiting enzyme for fatty acid synthesis in poultry, and thus resulting in lower fatty acid levels. Lower fatty acid levels might cause lower myristic acid, palmitic acid and oleic acid.

Santoso et al. (2018) reported that feeding katuk leaf or bay leaf at $5 \%$ had no effect on myristic acid, pentadecanoic acid, palmitic acid, linolenic acid, cis-5,8,11,14,17-eicosapentaenoic acid, and oleic acid. Fermentation and the combination of those herbs may change that pattern, because the present study showed that 


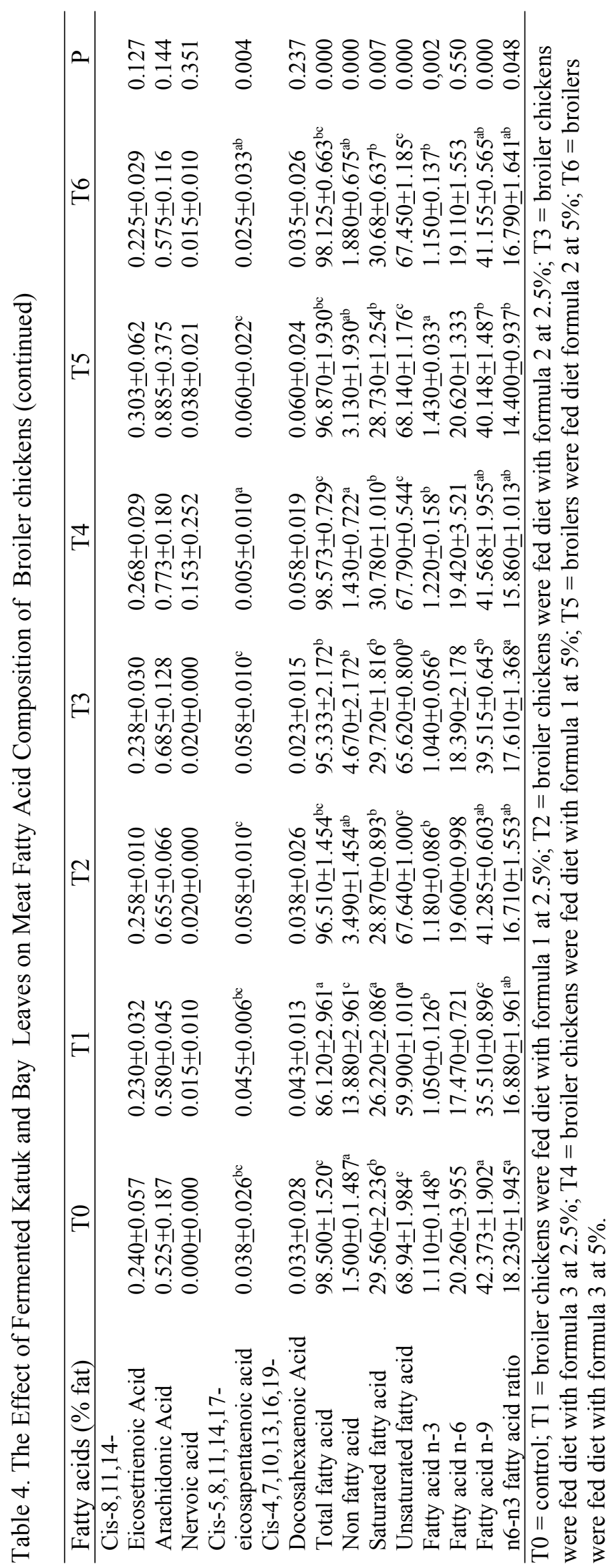


fermented katuk-bay leaves inclusion affected the above fatty acids. Santoso et al. (2015b) found that myristic acid was increased in broiler chicken fed a diet with fermented katuk leaf at $2.5 \%$, but its content was reduced when broiler chickens fed a diet with fermented katuk leaf powder at $5 \%$. This pattern was in contrast with the present study, which showed lower myristic acid content when broilers were fed a diet with fermented herbs at $2.5 \%$, but showed higher myristic acid content when broilers were fed a diet with fermented herbs at 5\%. Thus, fermented herbs inclusion changed the respond of broiler chickens. Santoso et al. (2015b) reported that the inclusion of fermented katuk leaf powder reduced oleic acid and linoleic acid, whereas in the present study showed that the inclusion of fermented herbs reduced oleic acid but not linoleic acid. Thus, the addition of fermented herbs changed meat fatty acid profiles.

Kamboh and Zhu (2013) reported that an increase in levels of flavonoid intake improved the ratio of n-6 to n-3 fatty acids and polyunsaturated fatty acids to saturated fatty acids in breast meats.

\section{CONCLUSION}

The inclusion of fermented katuk plus bay leaves reduced fat and cholesterol contents but increased or tended to increase protein, calcium, phosphorus, and iron contents and changed amino acid and fatty acid compositions in female broiler chickens.

\section{ACKNOWLEDGMENTS}

The authors thank the Director General of Higher Education, Ministry of Research, Technology and Higher Education, Indonesia under contract number 540/UN30.15/LT/2018. The authors also express our gratitude to all the staff of Institute for Research and Community Service of the University of Bengkulu for their services during the research. We also thank Anindita, Popi Purwanto, Syatri Utami, and Yusti Ari Daniel Nababan for assisting us to carry out this study.

\section{REFERENCES}

Abu-Dahab, R., V. Kasabri and F.U. Afifi. 2014. Evaluation of the volatile oil composition and antiproliferative activity of Laurus nobilis L. (Lauraceae) on breast cancer cell line models. Rec. Nat. Prod. 8(2):136-147.

Adriani, L., P. Roni, P. Bagus, Hendronoto and. A.W. Lengkey. 2012. Using bay leaf meal (Syzygium polyanthum, Wight) in ration on fat and cholesterol levels of quail meat (Coturnix coturnix japonica). Proc. The 1st Poult. Int. Sem. 2012.

Afrose, S., M.S. Hossain, T. Maki and H. Tsujii. 2010. Hypocholesterolemic response to karaya saponin and Rhodobacter capsulatus in broiler chickens. Asian-Aust. J. Anim. Sci. 23: 733-741.

Ahmed, A., I. Zulkifli, A.S. Farjam, N. Abdullah, J.B. Liang and E.A. Awad. 2014. Effect of solid state fermentation on nutrient content and ileal amino acids digestibility of canola meal in broiler chickens. Ital. J. Anim. Sci. 13:410-414.

Amani, R., S. Moazen, H. Shahbazian, K. Ahmadi and M.J. Jalali. 2014. Flavonoid-rich beverage effects on lipid profile and blood pressure in diabetic patients. World J. Diabetes 5(6):962-968.

Ari, M.M., B.A. Ayanwale, T.Z. Adama and E.A. Olatunji. 2012. Effects of different fermentation methods on the proximate composition, amino acid profile and some antinutritional factors (ANFs) in soybeans (Glycine max). Ferment. Technol. Bioeng. 2: 6-13.

Ayoub, N.A., A.N. Hashim, S.A. Hussein, N.M. Hegazi, H.M. Hassanein and M.A. Nawwar. 2013. Hepatoprotective effect of bay leaves crude extract on primary cultured rat hepatocytes. 1st Annual International Interdisciplinary Conference, AIIC 2013, 24-26 April, Azores, Portugal, pp. 647-655.

Breuer, G., W.A.C., Evers, J.H. de Vree, D.M.M. Kleinegris, D.E. Martens, R.H. Wijffels, P. P. Lamers. 2013. Analysis of fatty acid content and composition in microalgae. J. Vis. Exp. e50628, doi:10.3791/50628 (2013).

Çabuk, B., M.G. Nosworthy, A.K. Stone, D.R. Korber, T. Tanaka, J.D. House and M.T. Nickerson. 2018. Effect of fermentation on the protein digestibility and levels of nonnutritive compounds of pea protein concentrate. Food Technol. Biotech. 56(2): 257-264.

de Melo, T.S., P.R. Lima, K.M.M.B. Carvalho, T.M. Fontenele, F.R.N. Solon, A.R. Tomé, T.L.G. de Lemos, S.G. da Cruz Fonseca, 
F.A. Santos, V.S. Rao and M.G.R. de Queiroz. Ferulic acid lowers body weight and visceral fat accumulation via modulation of enzymatic, hormonal and inflammatory changes in a mouse model of high-fat diet-induced obesity. Braz. J. Med. Biol. Res. 50(1): e5630.

Gallardo, M.A., D. Pérez, P. Strobel, J. Cárcamo, F. Leighton, M.A. Gallardo, D. Pérez, P. Strobel, J. Cárcamo and F. Leighton. 2015. Cholesterol and vitamin E determination in broiler chickens fed canola oil. Arch. Med. Vet. 47:221-224.

Ginting, A.R., S. Sitorus and W. Astuti. Penentuan kadar asam amino esensial pada telur penyu dan telur bebek. Jurnal Kimia Mulawarman 14 (2): 91-99.

Gupta, C.P. 2014. Role of iron (Fe) in body. IOSR J. Appl. Chem. 7(11) Ver. II: 38-46.

Gupta, R.K., S.S. Gangoliya and N.K. Singh. 2015.Reduction of phytic acid and enhancement of bioavailable micronutrients in food grains. J. Food. Sci. Technol. 52(2): 676-684.

Hasan, M.N., M.Z. Sultam and M. Mar-E-Um. 2014. Significance of fermented food in nutrition and food science. J. Sci. Res. 6 (2): 373-386.

Jenkins, K.J. and A.S. Atwal. 1994. Effects of dietary saponins on fecal bile acids and neutral sterols, and availability of vitamins $A$ and $E$ in the chick. J. Nutr. Biochem. 5(3):134-137.

Joo, J.I., D.H. Kim, J.W. Choi and J.W. Yun. 2010. Proteomic analysis for antiobesity potential of capsaicin on white adipose tissue in rats fed with a high fat diet. J. Proteome Res. 9: 2977-2987.

Kamboh, A.A. and W.Y. Zhu. 2013. Effect of increasing levels of bioflavonoids in broiler feed on plasma anti-oxidative potential, lipid metabolites, and fatty acid composition of meat. Poultry Sci. 92: 454-461.

Khoo, H.E., A. Azlan and A. Ismail. 2015. Sauropus androgynus leaves for health benefits: hype and the science. Nat. Prod. J. 5: 115-123.

Kiyohara, H., T. Matsumoto and H. Yamada. 2004. Combination effects of herbs in a multi-herbal formula: Expression of juzentaiho-to's immuno-modulatory activity on the intestinal immune system. eCAM 2004; $1:(1) 83-91$.

Lee M.T., L.P. Lai, W.C. Lin, J.Y. Ciou, S.C.
Chang, B. Yu and T.T. Lee. 2017. Improving nutrition utilization and meat quality of broiler chickens through solid-state fermentation of agricultural by-products by Aureobasidium pullulans. Bra. J. Poultry Sci. 19(4): 645-654.

Li, B.H. and W.X. Tian. 2004. Inhibitory effects of flavonoids on animal fatty acid synthase. J. Biochem 135(1):85-91.

Mahmoud, R. and W. Elnour. 2013. Comparative evaluation of the efficacy of ginger and orlistat on obesity management, pancreatic lipase and liver peroxisomal catalase enzyme in male albino rats. Eur. Rev. Med. Pharmacol. Sci. 17:75-83.

Marfuah, N. 2016. Kadar kolesterol daging dan kualitas karkas ayam pedaging dengan penggunaan tepung bawang putih dalam ransum. J. Agrisains 17(3):116-122

Nan, L., O. Kehui, C. Jiaoying, Y. Wuying and W. Wenjun. 2014. Research on anti-oxidant activity and hypolipemic mechanism of Aloes flavonoids in mice. J. Food Nutr. Res. 2(9):601-607.

Narahari, D., P. Michealraja, A. Kirubakaran and T. Sujatha. 2005. Antioxidant, cholesterol reducing, immunomodulating and other health-promoting properties of herbal enriched designer eggs. XI the European Symposium on the Quality of Eggs and Egg Products Doorwerth, The Netherlands, 2326 May 2005.

Nie, C.X., W.J.Zhang, W.X. Ge, Y.P.Yiu, Y.Q. Wang and J.C. Liu. 2015. Effect of cottonseed meal fermented with yeast on the lipid-related gene expression in broiler chickens. Bra. J. Poultry Sci., Special Issue Nutrition-Poultry Feeding Additives/057064., October-December 2015.

Olagunju, A.I. and B.O.T. Ifesan. 2013. Changes in nutrient and antinutritional contents of sesame seeds during fermentation. JMBFS. 2:2407-2410.

Olaniyi, L.O. and S. Mehdizadeh. 2013. Effect of traditional fermentation as a pretreatment to decrease the antinutritional properties of rambutan seed (Nephelium lappaceum L.). International Conference on Food and Agricultural Sciences IPCBEE vol.55 (2013) C (2013) IACSIT Press, Singapore DOI: 10.7763/IPCBEE. 2013. V55. 13.

Pharthasarathy, V.A., T.J. Zachariah and B. Chempakam. 2008. Bay leaf. In: Chemistry of Spices. Pharthasarathy, V. A., B. 
Chempakam and T. J. Zachariah ed. CABI, Oxfordshire, UK.

Platel, K. and K. Srinivasan. 2017. Nutritional profile of chekurmanis (Sauropus androgynus), a less explored green leafy vegetable. Indian J. Nutr. Dietetics. 54(3): 243-252.

Pravina, P., D. Sayaji and M. Avinash. 2013. Calcium and its Role in Human Body. Int. J. Res. Pharm. Biomed. Sci. 4 (2): 658-668.

Qiong, F., Z. Chong, Z. Min, D. Ai-ni and Y. Hanhui. 2014. Determination of total polyphenols in Sauropus androgynus by Folin-Ciocalteu colorimetric method. J. South. Agric. 45(12):2230-2235.

Rahim, E.N.A.A., A. Ismail, M.N. Omar, U.N. Rahmat and W.A.N.W. Ahmad. 2018. GCMS analysis of phytochemical compounds in Syzygium polyanthum leaves extracted using ultrasound-assisted method. Harmacogn. J. 10(1):110-119.

Renkema, K.Y., R.T. Alexander, R.J. Bindels and J.G. Hoederop. 2008. Calcium and phosphate homeostasis: Concerted interplay of new regulators. Annals Med. 40:82-91.

Samad, A.P.A., U. Santoso, M.C. Lee and F.H. Nan, 2014. Effects of dietary katuk (Sauropus androgynus L. Merr.) on growth, non-specific immune and diseases resistance against Vibrio alginolyticus infection in grouper Epinephelus coioides. Fish Shellfish Immunol. 30:582-589.

Santoso, U., S. Ohtani and K. Tanaka. 2000. Tuchung leaf meal supplementation reduced an increase in lipid accumulation of chickens stimulated by dietary cholesterol. Asian-Aust. J. Anim. Sci. 13:1758-1763.

Santoso, U. and Sartini. 2001. Reduction of fat accumulation in broiler chickens by Sauropus androgynus (Katuk) leaf meal supplementation. Asian-Aust. J. Anim. Sci. 14:346-350.

Santoso, U., S. Ishikawa and K. Tanaka. 2010a. Effect of fermented chub mackerel extract on lipid metabolism of diabetic rats. J. Indonesian Trop. Anim. Agric. 35:158-164.

Santoso, U., T. Suteky and Y. Fenita. 2010b. Effects of supplementation of alkaloid and non alkaloid from Sauropus androgynus leaves on egg production and lipid profile in layer chicken. Anim. Prod. (Unsoed) 12(3):184-189.

Santoso U., Kususiyah and Y. Fenita, 2010c. The effect of Sauropus androgynus extract and lemuru oil on fat deposition and fatty acid composition of meat in broiler chickens. J. Indonesian Trop. Anim. Agric. 35:48-54.

Santoso, U., Y. Fenita and Kususiyah. 2015a. The effect of fermented Sauropus androgynus leaves on performance, fat deposition and carcass quality in broiler chicken. International Seminar on Promoting Local Resources for Food and Health, 12-13 October 2015, Bengkulu, Indonesia.

Santoso, U., Y. Fenita, Kususiyah and I.G.N.G. Bidura. 2015b. Effect of fermented Sauropus androgynus leaves on meat composition, amino acid and fatty acid compositions in broiler chickens. Pak. J. Nutr. 14:799-807.

Santoso, U., Y. Fenita and Kususiyah. 2017. The Effect of medicinal herb inclusion on hematologic status and blood lipid profiles in broiler chickens. Int. J. Poultry Sci. 16: 415-423.

Santoso, U., Y. Fenita, Kususiyah, O. Widiantoro and S. Kadarsih. 2018. The effect of medicinal herb on fat deposition, meat composition, amino acid and fatty acid composition of broiler meats. J. Indonesian Trop. Anim. Agric. 43(1):54-65.

Selvi, V.S. and A. Bhaskar. 2012. Phytochemical analysis and GC-MS profiling in the leaves of Sauropus Androgynus (L) Merr. Int. J. Drug Dev. Res. 4(1):162-167.

Shita, A.D.P. and Sulistiyani. 2010. Pengaruh kalsium terhadap tumbuh kembang gigi geligi anak. Stomatognatic. (3):40-44. 